\title{
Erratum: Current insights into hormonal regulation of microspore embryogenesis
}

\author{
Frontiers Production Office* \\ Frontiers Production Office, Frontiers, Lausanne, Switzerland
}

Keywords: crop species, hormonal regulation, microspore embryogenesis, plant growth regulators, phytohormone crosstalk

\section{An erratum on}

Current insights into hormonal regulation of microspore embryogenesis

by Żur, I., Dubas, E., Krzewska, M., and Janowiak, F. (2015) Front. Plant Sci. 6:424. doi:

OPEN ACCESS

Approved by:

Plant Science Editorial Office,

Frontiers, Switzerland

*Correspondence:

Frontiers Production Office,

production.office@frontiersin.org

Specialty section:

This article was submitted to

Plant Biotechnology,

a section of the journal

Frontiers in Plant Science

Received: 09 July 2015

Accepted: 09 July 2015

Published: 15 July 2015

Citation:

Frontiers Production Office (2015)

Erratum: Current insights into

hormonal regulation of microspore

embryogenesis.

Front. Plant Sci. 6:569.

doi: 10.3389/fpls.2015.00569
$10.3389 / f p l s .2015 .00424$

Reason for Erratum:

In the original article 2 of the references were cited incorrectly for the name of Teixeira da Silva, J. A. Below are the correct citations:

Ahmadi, B., Alizadeh, K., and Teixeira da Silva, J. A. (2012). Enhanced regeneration of haploid plantlets from microspores of Brassica napus L. using bleomycin, PCIB, and phytohormones. Plant Cell Tissue Organ Cult. 109, 525-533. doi: 10.1007/s11240-012-0119-8

Ahmadi, B., Shariatpanahi, M. E., and Teixeira da Silva, J. A. (2014). Efficient induction of microspore embryogenesis using abscisic acid, jasmonic acid and salicylic acid in Brassica napus L. Plant Cell Tissue Organ Cult. 116, 343-351. doi: 10.1007/s11240-013-0408-x

This error does not change the scientific conclusions of the article in any way.

The original article has been updated.

Copyright $(0) 2015$ Frontiers Production Office. This is an open-access article distributed under the terms of the Creative Commons Attribution License (CC BY). The use, distribution or reproduction in other forums is permitted, provided the original author(s) or licensor are credited and that the original publication in this journal is cited, in accordance with accepted academic practice. No use, distribution or reproduction is permitted which does not comply with these terms. 